ORIGINAL ARTICLE

\title{
Sanitizing cinnamaldehyde solutions against Pseudomonas aeruginosa biofilms formed on stainless steel surfaces
}

\author{
Soluções sanitizantes de cinamaldeído para biofilmes de \\ Pseudomonas aeruginosa formados em superfície de aço \\ inoxidável
}

\section{Lívio Antônio Silva Pereira1* (1), Maíra Maciel Mattos de Oliveira², Heloísa Helena de Abreu Martins ${ }^{3}$, Letícia Andrade do Vale ${ }^{3}$, Silas Rodrigo Isidoro³, Diego Alvarenga Botrel ${ }^{1}$, Roberta Hilsdorf Piccoli ${ }^{3}$}

\author{
${ }^{1}$ Universidade Federal de Lavras, Engenharia de Biomateriais, Lavras/MG - Brasil \\ ${ }^{2}$ Instituto Federal de Educação de Ciência e Tecnolgia do Espírito Santo, Venda Nova do Imigrante/ES - Brasil \\ ${ }^{3}$ Universidade Federal de Lavras, Departmento de Ciência dos Alimentos, Lavras/MG - Brasil \\ *Corresponding author: Lívio Antônio Silva Pereira, ${ }^{1}$ Universidade Federal de Lavras, Engenharia de \\ Biomateriais, Av. Doutor Sylvio Menicucci, 1001 Kennedy, Aquenta Sol, CEP: 37200-000, Lavras/MG, Brasil, e- \\ mail: livioanpe@yahoo.com.br
}

\begin{abstract}
Pseudomonas aeruginosa is an opportunistic pathogen capable of forming biofilms of great relevance to medical microbiology and the food industry. Essential oil (EOs) constituents have been researched as new strategies for the control of biofilms. In the present study cinnamaldehyde was shown to be an effective EO against the planktonic cells of $P$. aeruginosa strains $(p<0.05)$. Thus it was used to prepare sanitizing solutions, which were tested against $P$. aeruginosa biofilms formed on stainless steel surfaces. Cinnamaldehyde showed antibacterial activity against sessile $P$. aeruginosa cells $(p<0.05)$. A 100\% (5.87 log-reduction) elimination of viable bacterial cells was obtained after treatment with a 6xMIC ( $0.06 \%$ Minimal Inhibitory Concentration) solution for the strain ATCC 9027 . Sanitizing cinnamaldehyde solutions can be used as new alternatives to control such microbial sessile communities in food industries.
\end{abstract}

Keywords: Essential oil constituent; Natural sanitizing solution; Bacterial adhesion; Bacterial biofilms; Industrial surfaces; Pseudomonas aeruginosa.

\section{Resumo}

Pseudomonas aeruginosa é um patógeno oportunista capaz de formar biofilmes de grande relevância para a microbiologia médica e para a indústria de alimentos. Os constituintes do óleo essencial (OE) têm sido pesquisados como novas alternativas para o controle do biofilme. Neste estudo, o cinamaldeído mostrou-se eficaz como OE 
contra células planctônicas de cepas de $P$. aeruginosa $(p<0,05)$ e foi então utilizado para a preparação de soluções sanitizantes que, por sua vez, foram testadas contra biofilmes de $P$. aeruginosa formados em superfície de aço inoxidável. Cinamaldeído mostrou atividade antibacteriana contra células sésseis de $P$. aeruginosa $(p<0,05)$. Para a estirpe ATCC 9027, foi obtida uma eliminação de células bacterianas viáveis em 100\% (5,87 log-redução), após tratamento com a solução 6xMIC (0,06\% Concentração Inibitória Mínima). As soluções sanitizantes de cinamaldeído podem ser novas alternativas para o controle dessas comunidades sésseis microbianas na indústria alimentícia.

Palavras-chave: Constituinte de óleo essencial; Solução sanitizante natural; Adesão bacteriana, Biofilme bacteriano; Superfícies industriais; Pseudomonas aeruginosa.

\section{Introduction}

Microorganisms have a natural tendency to attach to moist surfaces, multiply and remain in the viscous matrix composed of extracellular polymeric substances (EPS), forming biofilms (Simões et al., 2010).

Biofilms constitute a protected mode of growth that allows the microorganisms to survive in hostile environments. These biofilms can become 10-1000 times more resistant to the effects of antimicrobial agents than their planktonic counterparts. Thus it is difficult to control their growth in industrial and hospital environments, leading to a variety of contaminations in the food industry, causing food spoilage and public health problems, such as outbreaks of foodborne pathogens (York, 2017).

Amongst the microorganisms involved, Pseudomonas aeruginosa is considered a model organism to study biofilm formation, due to its clinical importance and propensity to develop biofilms resistant to sanitizing agents. This rod-shaped, mobile, Gram-negative aerobic bacteria can survive and multiply in several environments and in a wide temperature range. P. aeruginosa is commonly found in the environment, the water, the soil, and in several vegetations around the world. It rarely causes sickness in healthy individuals, but is a predominant cause of opportunistic nosocomial infections. Moreover, many diseases related to $P$. aeruginosa biofilms are resistant to most antimicrobial therapies. Several problems related to $P$. aeruginosa biofilms such as endocarditis, cystic fibrosis and mechanical ventilation pneumonia have been reported (Lalawmpuii \& Chatli, 2017).

According to Kenneth \& Ray (2004) water or foods containing P. aeruginosa do not present risks. However, the growth of $P$. aeruginosa can cause the spoilage of foods from different origins. Some strains can form biofilms on abiotic industrial surfaces or even grow at refrigeration temperatures, which indicates that this species may result in losses for the food industry.

Thus the control of microbial biofilms formed by $\mathrm{P}$. aeruginosa is necessary in both clinical and industrial areas. In this context, the development of new and efficient alternatives to control biofilms has emerged as an area of research in continuous expansion. A recently published study has shown that essential oils (EOs) and their constituents present antimicrobial activity against the biofilms formed by different species of microorganisms (Flemming et al., 2016).

EOs are complex volatile substances extracted from plant materials, that present secondary metabolites such as terpenoids, terpenes and aromatic compounds derived from phenylpropane. The phenylpropanoid bark constituent cinnamaldehyde, presents effective action against both planktonic and sessile bacterial cells. Campana et al. (2017) evaluated the EOs Cinnamomum cassia and Salvia officinalis against $S$. aureus biofilms. Different microemulsions were tested against the biofilms and up to $68 \%$ biofilm removal was noted after 90 min exposure to the essential oils. Oliveira et al. (2012b) studied the antibacterial effects of cinnamaldehyde against enteropathogenic Escherichia coli (EPEC) and Listeria monocytogenes biofilms and an effect of cinnamaldehyde as a chemical sanitizer was detected, eliminating or reducing the cells from sessile bacteria. Kavanaugh \& Ribbeck (2012) observed that the EO Cinnamomum aromaticum and the compound cinnamaldehyde eradicated the biofilm formed by $P$. aeruginosa on an MBEC device (a modified microtiter plate), proving to be more effective than important antibiotics. However, there are few studies on the control of $P$. aeruginosa biofilms, especially regarding those formed on industrial surfaces, and the use ofcinnamaldehyde sanitizing solutions. Of the five compounds tested (cinnamaldehyde, eugenol, carvacrol, 
citral and terpinen-4-ol), cinnamaldehyde was evaluated as the most effective EO compound against the planktonic cells of three strains of $P$. aeruginosa and their biofilms.

\section{Materials and methods}

\subsection{Bacterial strains, inoculum storage and standardization}

Pseudomonas aeruginosa ATCC 15442, 27853 and 9027 were provided by the National Institute of Quality Control in Health - INCQS of the Oswaldo Cruz Foundation - FIOCRUZ. (Rio de Janeiro, RJ, Brazil). The strains were stored at $-18{ }^{\circ} \mathrm{C}$ in Tryptone Soya Broth (TSB) containing $20 \%(\mathrm{v} / \mathrm{v})$ glycerol, and the McFarland scale was used for standardization. Colonies present on the surface of the Tryptone Soy Agar (TSA) were inoculated into a $0.85 \%$ saline solution (w/v) after incubation at $37{ }^{\circ} \mathrm{C}$ for $24 \mathrm{~h}$ until a turbidity standard of 0.5 , corresponding to $1.5 \times 10^{8} \mathrm{CFU} \mathrm{mL}^{-1}(\mathrm{OD}$ at $620 \mathrm{~nm}=0.08$ to 0.1$)$.

\subsection{Preliminary tests on planktonic cells}

\subsubsection{Screening}

The EO compounds used in this stage were eugenol, carvacrol, cinnamaldehyde, citral and terpinen-4-ol, all of which were acquired from Sigma Aldrich. They were previously diluted in dimethyl sulfoxide (DMSO) (proportion of 1:1), and the agar diffusion technique (adapted from Oliveira et al. (2012a)) was applied.

Aliquots $(100 \mu \mathrm{L})$ of standardized bacterial suspensions were plated on Mueller Hinton agar containing $0.5 \%$ Tween 80 . Filter paper discs $(6 \mathrm{~mm}$ in diameter) were placed in the middle of the culture surface and at the centre of the dish. The compound solutions were added $(6 \mu \mathrm{L})$ to the filter paper discs and incubated at $37{ }^{\circ} \mathrm{C}$ for $24 \mathrm{~h}$. The inhibition zones of the paper discs were measured using a digital pachymeter. The average of two diametrically opposite measurements was calculated, and the result was expressed in millimetres (mm).

\subsubsection{Minimal Inhibitory Concentrations (MICs)}

In this stage, only cinnamaldehyde was used.

The broth microdilution method described by Oliveira et al. (2012a) was used to evaluate the MICs. Concentrations of $(0.00 ; 0.01 ; 0.03 ; 0.06 ; 0.12 ; 0.25 ; 0.50$ and $1.00 \%(\mathrm{v} / \mathrm{v}))$ were prepared in flat-bottomed 96-well polystyrene microplates (SPL Life Sciences, Pocheon, South Korea). The concentrations were obtained by homogenizing the compound in TSB containing $0.5 \%(\mathrm{v} / \mathrm{v})$ Tween 80 , in a final volume of $150 \mu \mathrm{L} .10 \mu \mathrm{L}$ of standardized bacterial suspension were added to the culture media and three repetitions were carried out. For all concentrations, culture mediums were also prepared without the bacterial inoculum, containing only the compound diluted in the culture medium. The microplates were capped and incubated at $37{ }^{\circ} \mathrm{C}$ for $24 \mathrm{~h}$. The absorbance was measured at $620 \mathrm{~nm}$ in a microplate reader (Anthos 2010, Biochrom, Cambridge, United Kingdom), prior to incubation (time zero) and after $24 \mathrm{~h}$. The microplates were gently shaken by hand before the absorbance reading after the incubation period $(24 \mathrm{~h})$. The MICs corresponded to the lowest concentrations that resulted in the complete inhibition of bacterial growth.

\subsection{Bacterial biofilm formation}

Stainless steel (type AISI 304 (polish \#4) $(1 \times 8 \times 18 \mathrm{~mm}))$ plates were previously sanitized and sterilized (Oliveira et al., 2012a). The plates were arranged in test tubes $(5 \times 2 \mathrm{~cm})$ containing $4.59 \mathrm{~mL}$ of TSB, and $410 \mu \mathrm{L}$ of a standardized bacterial suspension added and incubated at $37^{\circ} \mathrm{C}$ for $24 \mathrm{~h}$ under static conditions. 


\subsection{Application of cinnamaldehyde solutions to the stainless steel plates}

The plates were removed from the test tubes, washed three times with $0.1 \%$ peptone water $(\mathrm{w} / \mathrm{v})$ to remove non-adhered cells, and submitted to the following four treatments: (i) sterile distilled water containing $0.5 \%$ (v/v) Tween 80 (control solution); (ii) cinnamaldehyde at the MIC concentration diluted in sterile distilled water containing $0.5 \%(\mathrm{v} / \mathrm{v})$ Tween 80 ; (iii) cinnamaldehyde at $3 \times$ MIC concentration diluted in sterile distilled water containing $0.5 \%(\mathrm{v} / \mathrm{v})$ Tween 80 ; and (iv) cinnamaldehyde at $6 \times$ MIC concentration diluted in sterile distilled water containing $0.5 \%(\mathrm{v} / \mathrm{v})$ Tween 80 . The treatments were applied in test tubes and maintained for 15 minutes at room temperature under static conditions.

\subsection{Adhered bacterial cells quantification}

The plateswere washed three times using peptone water to remove the residual cinnamaldehyde, and then transferred to conical Falcon tubes ( $50 \mathrm{~mL}$ capacity) containing $10 \mathrm{~mL}$ of peptone water and six glass beads ( $3 \mathrm{~mm}$ diameter). The falcon tubes were then stirred in a vortex for 2 minutes. Plates that were not submitted to any treatment were also sampled and represented the biofilm count. Serial dilutions were prepared in $9 \mathrm{~mL}$ of peptone water. The bacteria were cultured in TSA, plated in duplicate using the spread plate technique $(100 \mu \mathrm{L})$, incubated at $37^{\circ} \mathrm{C}$ for $24 \mathrm{~h}$ and the counts obtained in $\mathrm{Log} \mathrm{CFU} \mathrm{cm}{ }^{-2}$, with a detection limit of $1.47 \log \mathrm{CFU} \mathrm{cm}{ }^{-2}$.

\subsection{Experimental design and statistical analysis}

A $3 \times 4$ (bacterial strains $\times$ EO compounds) factorial scheme with a completely randomized design (CRD) was used with three repetitions for the screening step. Significant differences $(p<0.05)$ were verified by the variance analysis (ANOVA) and the averages compared by Tukey's test at $5 \%$ probability. The diameter of the inhibition halos in mm was considered as the response variable.

The CRD was carried out with three repetitions to evaluate biofilm formation by different strains of P. aeruginosaa. Significant differences $(p<0.05)$ were tested by ANOVA. The response variable was

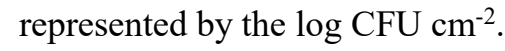

The CRD was also carried out with three repetitions to evaluate the antibacterial effect of the cinnamaldehyde solutions against the $P$. aeruginos a strain biofilms. Significant differences $(p<0.05)$ were verified by ANOVA. Each bacterial strain was individually evaluated and the Tukey test at $5 \%$ probability used. The response variable was expressed in log-reduction, which was the difference between the log of the initial cell count and the log of the surviving cells as compared to the control and antibacterial treatments (MIC, $3 \times$ MIC and $6 \times$ MIC). The Sisvar software version 4.6 (Department of Exact Sciences, Federal University of Lavras, Lavras, Minas Gerais, Brazil) was used.

\section{Results}

\subsection{Tests on planktonic cells}

It was found that the compound citral presentd no antibacterial activity against any of the three $P$. aeruginosa strains tested by the disc diffusion technique; and no difference was observed between the strain sensitivity to the compounds that showed antibacterial effects (eugenol, carvacrol, cinnamaldehyde and terpinen-4-ol) $(p>0.05)$. However, cinnamaldehyde was more effective than the others $(p<0.05)$, presenting an average inhibition halo (corresponding to all the strains) of $12.72 \mathrm{~mm}$. Eugenol, carvacrol and terpinen-4-ol compounds presented mean inhibition halos of 7.33, 6.94 and $7.69 \mathrm{~mm}$, respectively (Figure 1). 


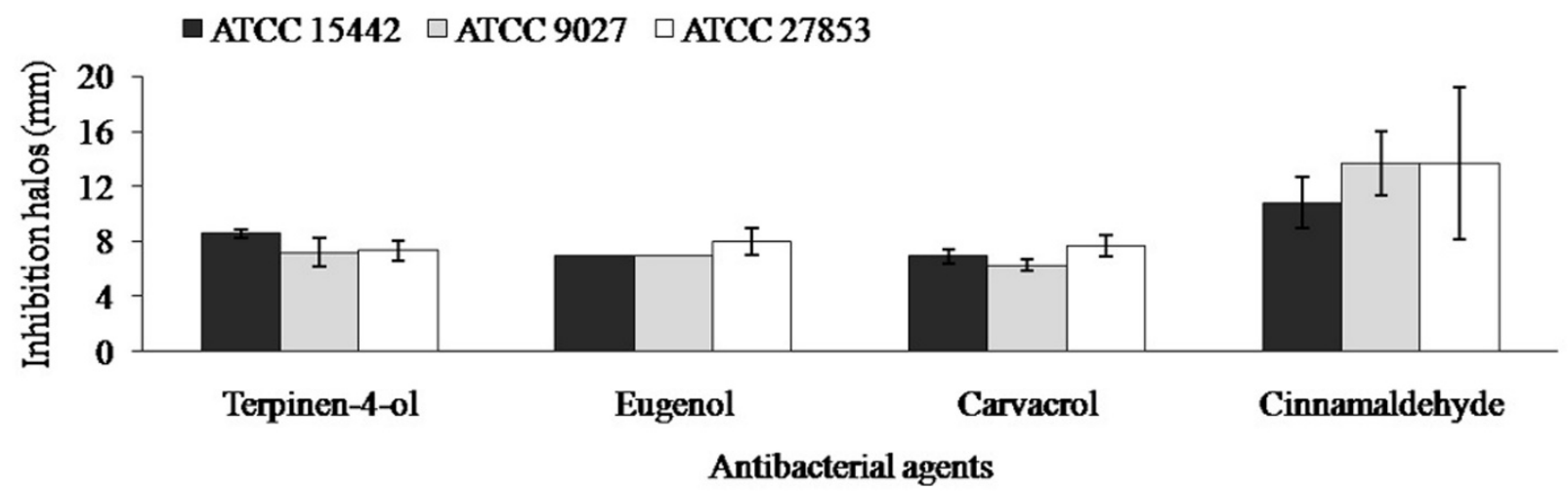

Figure 1. Mean Inhibition halos of different compounds.

The cinnamaldehyde MICs obtained were $0.12 \%$ for P. aeruginosa ATCC 15442 and 27853 and $0.06 \%$ for P. aeruginosa ATCC 9027.

\subsection{Biofilm formation and application of cinnamaldehyde solutions}

All the $P$. aeruginosa strains were able to adhere to stainless steel surfaces and form biofilm. The bacterial cell counts of the untreated plates (biofilm) were $6.55 \pm 0.21,5.87 \pm 0.50$ and $6.58 \pm 0.23 \mathrm{Log}$ CFU cm${ }^{-2}$ for $P$. aeruginosa ATCC 15442, 9027 and 27853, respectively. No differences amongst the adhered cell numbers were verified $(p>0.05)$.

Cinnamaldehyde showed antibacterial activity against the sessile cells of $P$. aeruginosa biofilms $(p<0.05)$. However, this effect differed in intensity and behaviour according to the strain tested. All the treatments containing cinnamaldehyde (MIC, $3 \times \mathrm{MIC}$ and $6 \times \mathrm{MIC}$ ) presented an antibacterial effect greater than that of the control (with no cinnamaldehyde) $(p<0.05$ ), for the P. aeruginosa ATCC 15442. $6 \times \mathrm{MIC}$ was the most effective treatment for the $P$. aeruginosa ATCC 9027 and 27853 strains $(p<0.05)$. However, it is important to emphasize that a $100 \%$ (5.87 log-reduction) viable bacterial cell elimination was obtained only for the strain ATCC 9027 with the $6 \times$ MIC solution application. It was possible to eliminate $85.05 \%$ (5.57 log-reduction) and $78.72 \%$ (5.18 log-reduction) of the viable biofilm cells of the ATCC 15442 and 27853 strains respectively (Table 1).

Table 1. Treatments of the Pseudomonas aeruginosa (ATCC 15442, ATCC 9027, ATCC 27853) biofilms with different concentrations of cinnamaldehyde diluted in sterile distilled water containing $0.5 \%(\mathrm{v} / \mathrm{v})$ of tween 80 .

\begin{tabular}{ccccccc}
\hline \multirow{2}{*}{$\begin{array}{c}\text { Cinnamaldehyde } \\
\text { solutions }\end{array}$} & \multicolumn{3}{c}{ Pseudomonas aeruginosa strains } \\
\cline { 2 - 7 } & ATCC 15442 & \multicolumn{2}{c}{ ATCC 9027 } & \multicolumn{1}{c}{ ATCC 27853 } \\
\cline { 2 - 7 } & Log-reduction $^{\mathbf{3}}$ & $\mathbf{\%}^{\mathbf{4}}$ & Log-reduction $^{\mathbf{3}}$ & $\mathbf{\%}^{\mathbf{4}}$ & Log-reduction & $\mathbf{\%}^{\mathbf{4}}$ \\
Control $^{1}$ & $0.97 \pm 0.15^{\mathrm{a}}$ & 14.78 & $1.69 \pm 0.22^{\mathrm{a}}$ & 28.76 & $0.86 \pm 0.09^{\mathrm{a}}$ & 13.00 \\
$\mathrm{MIC}^{2}$ & $4.64 \pm 0.19^{\mathrm{b}}$ & 70.84 & $2.04 \pm 0.05^{\mathrm{a}}$ & 34.70 & $1.97 \pm 0.23^{\mathrm{b}}$ & 29.97 \\
$3 \times \mathrm{MIC}^{2}$ & $5.80 \pm 1.06^{\mathrm{b}}$ & 88.56 & $4.50 \pm 0.28^{\mathrm{b}}$ & 76.68 & $4.02 \pm 0.13^{\mathrm{c}}$ & 61.02 \\
$6 \times \mathrm{MIC}^{2}$ & $5.57 \pm 0.69^{\mathrm{b}}$ & 85.05 & $5.87 \pm 0.00^{\mathrm{c}}$ & 100.00 & $5.18 \pm 0.33^{\mathrm{d}}$ & 78.72 \\
\hline
\end{tabular}

${ }^{1}$ Containing no cinnamaldehyde. ${ }^{2}$ Minimum inhibitory concentrations (MIC). The MICs for each strain tested can be found in Table $1 .{ }^{3}$ The log-reduction was the difference between the log of the initial cells counts (biofilm) and the log of the surviving cells after the antibacterial treatments. ${ }^{4}(\log$-reductions $\times 100) /$ viable cell count of untreated plates. The results were equivalent to the average of three repetitions \pm the standard deviation. Means followed by the same letters in the same column do not differ from each other according to the Tukey test at $5 \%$ probability. 


\section{Discussion}

EOs and their compounds appear to act on the cell wall or cell membrane (Kavanaugh \& Ribbeck, 2012). The essential oils pass through the bacterial cell wall and cytoplasmic membrane, break the structure of the different layers of polysaccharides, fatty acids and phospholipids and permeabilize them. Bouhdid et al. (2009) noted that changes in the bacterial membrane of P. aeruginosa ATCC 27853 were induced by exposure to Cinnamomum verum EO, leading to potential membrane breakdown, membrane-selective permeability loss and cell death.

There are some clusters of microorganisms that present less sensitivity to the action of EOs and P. aeruginosa presents this profile. (Flemming et al., 2016). This resistance is related to efflux mechanisms of and inhibition dependent on porin and an outer membrane impermeable to EO molecules. Thus, its use as a model microorganism to test the antimicrobial effects of biofilms is of interest. Studies carried out by Prabuseenivasan et al. (2006) and Mayaud et al. (2008) demonstrated that the cinnamon bark EO is one of the most effective EOs against $P$. aeruginosa strains. This was also observed in the present study, where the compound cinnamaldehyde stood out from the others tested (eugenol, carvacrol, citral and terpinen-4-ol) against the planktonic cells of $P$. aeruginosa strains. It was therefore selected to prepare and apply the sanitizing solutions.

According to Oliveira et al. (2012b), it is important test natural sanitizers on the surfaces of materials used in the food industry. Stainless steel is widely used in the food industry for the equipment employed in food processing. Among its advantages are its easy hygiene and resistance to corrosion.

The $P$. aeruginosa strains tested (ATCC 15442, 9027 and 27853) were able to form biofilms on stainless steel surfaces, with counts ranging from $5.87 \mathrm{Log}$ CFU cm cm $^{-2}$ (ATCC 9027) to $6.58 \mathrm{Log} \mathrm{CFU} \mathrm{cm} \mathrm{cm}^{-2}$ (ATCC 27853). There are few publications concerning the adhesion of $P$. aeruginosa on the surfaces of materials used in the food industry, such as stainless steel (Caixeta et al., 2012). Most studies used the wells of microplates as the test surface and were carried out with a clinical microbiology perspective (Tré-Hardy et al., 2010). The bacterial adhesion values observed in this study demonstrated that $P$. aeruginosa strains can become a risk to food quality if the hygiene programs are not properly applied. Moreover, it is necessary to develop new strategies to control bacteria resistant to sanitization. So a good option would be the use of EOs (Rasamiravaka et al., 2015). According to Oliveira et al. (2012b), the use of EOs and their constituents can act more effectively on microorganisms resistant to the usual chemical sanitizers. The study of commercial chemical sanitizers in relation to Pseudomonas has already been widely explored in the literature and the results can be compared with the results obtained in the present work, where in some cases, they may be inferior. Shen et al. (2012) evaluated the influence of formulations with sodium hypochlorite on the formation of Salmonella and Pseudomonas biofilms on stainless steel, showing efficiency at dosages higher than those used here. Meesilp \& Mesil (2018) tested the effect of microbial sanitizers on the reduction of the formation of Staphylococcus aureus and Pseudomonas aeruginosa biofilms on stainless steel by UHT milk cultures, using the sanitizing agents oxisan and chlorine, with a mean sanitizing concentration of $4 \%$.

The $P$. aeruginosa biofilms were more resistant to cinnamaldehyde (Table 1) than the planktonic cells (Figure 1) in this study. Several factors can contribute to biofilm resistance. The biofilm cell physiology differs from the plant cell physiology, and thus they have specific protection factors that can influence the sanitizing action. The presence of bacteria in biofilms, especially those found in more internal regions, can reduce their growth rates and metabolism, being less sensitive to antimicrobials. These factors are related to increased resistance, including high population densities in the biofilms. The adsorbent action by the extracellular polymers reduces the availability of the antimicrobial agent, and the matrix of extracellular polymeric substances can cause the physical reduction of the penetration capacity of the antimicrobial agent or cause its inactivation.(Lalawmpuii \& Chatli, 2017).

Sanitizing solutions containing cinnamaldehyde showed antibacterial effects against biofilms formed by the three P. aeruginosa strains $(p<0.05)$ when the $6 \times$ MIC treatment was used (Table 1$)$. These results are 
novel in the field, since there was no previous knowledge about the antibacterial action of cinnamaldehyde sanitizing solutions against $P$. aeruginosa biofilms formed on stainless steel. The cinnamaldehyde (3-phenyl2-propenal) EO aromatic constituent is a natural antimicrobial compound that can be isolated from cinnamon. Cinnamaldehyde is Generally Recognized as Safe (GRAS) and approved for use in the food industry (Rogiers et al., 2017).

Differences in the physiology of the strains tested regarding their sensitivity to the sanitizing solutions containing cinnamaldehyde were also noted. This emphasizes the importance of using different strains to study the antimicrobial activity. Similar occurrences have been reported in previous studies that evaluated the susceptibility of different $P$. aeruginosa strains to antibiotics and other antimicrobial agents (Lowbury et al., 1969; Russell \& Mills, 1974). P. aeruginosa ATCC 27853 and 15442 were more resistant to the antibacterial solutions used. The biofilms of these strains were not completely eliminated (Table 1). This behaviour was similar to that of the same strains in the planktonic form, in which they presented higher MIC values. Some alternatives can be further tested in order to enhance the antibacterial effect of cinnamaldehyde sanitizing solutions against the $P$. aeruginosa ATCC 27853 and 15442, aiming to eliminate $100 \%$ of the viable sessile cells. In general, the use of sanitizing solutions containing EOs will not significantly change the usual hygiene methodology applied to surfaces in the food industry. It is important to emphasize that some parameters such as the contact time and the temperature require some adjustments for the application of antimicrobial agents on an industrial scale. According to Oliveira et al. (2012b), no residual odour occurs at the lower EO solution concentrations. Moreover, they can be easily removed (Oliveira, et al., 2012b).

\section{Conclusions}

Cinnamaldehyde sanitizing solutions were effective against the biofilms formed by the $P$. aeruginosa strains on stainless steel surfaces. Thus, they could be new alternatives to control these microbial sessile communities in food industries. As $P$. aeruginos $a$ is one of the most resistant microorganisms to antimicrobial treatments, the results obtained in this work can probably be extrapolated to other microorganisms. The use of EO constituents is an easy alternative to prepare sanitizer solutions that can easily be standardized and reproduced. However, more studies should be done to check the storage stability of these solutions. Future studies must also be carried out under the industrial conditions (in which biofilms are complex and heterogeneous communities) to demonstrate the real effectiveness of these solutions.

\section{Acknowledgements}

This work is part of a project financed by the Coordination for the Improvement of Higher Level Education Personnel (CAPES). The Research Support Foundation of the State of Minas Gerais (FAPEMIG) and the National Council of Technological and Scientific Development (CNPq) also contributed with financial support and scholarships.

\section{References}

Bouhdid, S., Abrini, J., Zhiri, A., Espuny, M. J., \& Manresa, A. (2009). Investigation of functional and morphological changes in pseudomonas aeruginosa and staphylococcus aureus cells induced by origanum compactum essential oil. Journal of Applied Microbiology, 106(5), 1558-1568. PMid:19226402. http://dx.doi.org/10.1111/j.1365-2672.2008.04124.x

Caixeta, D. S., Scarpa, T. H., Brugnera, D. F., Freire, D. O., Alves, E., Abreu, L. R. D., \& Piccoli, R. H. (2012). Chemical sanitizers to control biofilms formed by two Pseudomonas species on stainless steel surface. Food Science and Technology, 32(1), 142-150. http://dx.doi.org/10.1590/S0101-20612012005000008

Campana, R., Casettari, L., Fagioli, L., Cespi, M., Bonacucina, G., \& Baffone, W. (2017). Activity of essential oil-based microemulsions against Staphylococcus aureus biofilms developed on stainless steel surface in different culture media and growth conditions. International Journal of Food Microbiology, 241, 132-140. PMid:27770682.

http://dx.doi.org/10.1016/j.ijfoodmicro.2016.10.021 
Flemming, H. C., Wingender, J., Szewzyk, U., Steinberg, P., Rice, S. A., \& Kjelleberg, S. (2016). Biofilms: an emergent form of bacterial life. Nature Review Microbiology, 14(9), 563-575. PMid:27510863.

Kavanaugh, N. L., \& Ribbeck, K. (2012). Selected antimicrobial essential oils eradicate pseudomonas spp. and Staphylococcus aureus biofilms. Applied and Environmental Microbiology, 78(11), 4057-4061. PMid:22467497.

http://dx.doi.org/10.1128/AEM.07499-11

Kenneth, J. R., \& Ray, C. G. (2004). Spread and control of infection. Journal, 1(11), 173-258.

Lalawmpuii, H., \& Chatli, M. K. (2017). Battling biofilms. Dairy Industries International, 82(10), 36-39.

Lowbury, E. J. L., Lilly, H. A., Kidson, A., Ayliffe, G. A. J., \& Jones, R. J. (1969). Sensitivity of Pseudomonas aeruginosa to antibiotics: emergence of strains highly resistant to carbenicillin. Lancet, 294(7618), 448-452. http://dx.doi.org/10.1016/S01406736(69)90163-9

Mayaud, L., Carricajo, A., Zhiri, A., \& Aubert, G. (2008). Comparison of bacteriostatic and bactericidal activity of 13 essential oils against strains with varying sensitivity to antibiotics. Letters in Applied Microbiology, 47(3), 167-173. PMid:19552780. http://dx.doi.org/10.1111/j.1472-765X.2008.02406.x

Meesilp, N., \& Mesil, N. (2018). Effect of microbial sanitizers for reducing biofilm formation of Staphylococcus aureus and Pseudomonas aeruginosa on stainless steel by cultivation with UHT milk. Food Science and Biotechnology, 28(1), 289-296. PMid:30815321. http://dx.doi.org/10.1007/s10068-018-0448-4

Oliveira, M. M. I. M., Brugnera, D. F., Nascimento, J. A., \& Piccoli, R. H. (2012a). Control of planktonic and sessile bacterial cells by essential oils. Food and Bioproducts Processing, 90(4), 809-818. http://dx.doi.org/10.1016/j.fbp.2012.03.002

Oliveira, M. M. M., Brugnera, D. F., Nascimento, J. A., Batista, N., \& Piccoli, R. H. (2012b).Cinnamon essential oil and cinnamaldehyde in the control of bacterial biofilms formed on stainless steel surfaces. European Food Research and Technology, 234(5), 821-832. http://dx.doi.org/10.1007/s00217-012-1694-y

Prabuseenivasan, S., Jayakumar, M., \& Ignacimuthu, S. (2006). In vitro antibacterial activity of some plant essential oils. BMC Complementary and Alternative Medicine, 6(1), 39. PMid:17134518. http://dx.doi.org/10.1186/1472-6882-6-39

Rasamiravaka, T., Labtani, Q., Duez, P., \& El Jaziri, M. (2015). The formation of biofilms by pseudomonas aeruginosa: a review of the natural and synthetic compounds interfering with control mechanisms. BioMed Research International, 2015, 759348. PMid:25866808. http://dx.doi.org/10.1155/2015/759348

Rogiers, G., Kebede, B. T., Van Loey, A., \& Michiels, C. W. (2017). Membrane fatty acid composition as a determinant of Listeria monocytogenes sensitivity to trans-cinnamaldehyde. Research in Microbiology, 168(6), 536-546. PMid:28342836. http://dx.doi.org/10.1016/j.resmic.2017.03.001

Russell, A. D., \& Mills, A. P. (1974). Comparative sensitivity and resistance of some strains of Pseudomonas aeruginosa and Pseudomonas stutzeri to antibacterial agents. Journal of Clinical Pathology, 27(6), 463-466. PMid:4369876. http://dx.doi.org/10.1136/jcp.27.6.463

Shen, C., Luo, Y., Nou, X., Bauchan, G., Zhou, B., Wang, Q., \& Millner, P. (2012). Enhanced inactivation of salmonella and pseudomonas biofilms on stainless steel by Use of T-128, a fresh-produce washing aid, in chlorinated wash solutions. Applied and Environmental Microbiology, 78(19), 6789-6798. PMid:22752180. http://dx.doi.org/10.1128/AEM.01094-12

Simões, M., Simões, L. C., \& Vieira, M. J. (2010). A review of current and emergent biofilm control strategies. Food Science and Technology, 43(4), 573-583. https://doi.org/10.1016/j.lwt.2009.12.008.

Tré-Hardy, M., Nagant, C., El Manssouri, N., Vanderbist, F., Traore, H., Vaneechoutte, M., \& Dehaye, J. P. (2010). Efficacy of the combination of tobramycin and a macrolide in an in vitro Pseudomonas aeruginosa mature biofilm model. Antimicrobial Agents and Chemotherapy, 54(10), 4409-4415. PMid:20696878. http://dx.doi.org/10.1128/AAC.00372-10

York, A. (2017). Host response: fungal safeguards in the gut. Nature Reviews. Microbiology, 16(1), 1. PMid:29217846. http://dx.doi.org/10.1038/nrmicro.2017.155 